\title{
EFFECT OF DEUTECTOMY, FASTING AND ENVIRONMENTAL TEMPERATURE ON FREE FATTY ACID CONCENTRATION IN THE BLOOD PLASMA OF CHICKENS IN THE FIRST WEEK AFTER HATCHING
}

\author{
E. BARANYIOVÁ, S. STANDARA \\ Department of Physiology, University of Veterinary Science, 61242 Brno and \\ Veterinary Research Institute, $62132 \mathrm{Brno}$
}

Received fanuary 18, 1980

\begin{abstract}
Baranyiová E., S. Standara: Effect of Deutectomy, Fasting and Environmental Temperature on Free Fatty Acid Concentration in the Blood Plasma of Chickens in the First Week after Hatching. Acta vet. Brno, 49, 1980: 187-192.

Effects of food intake, fasting, environmental temperature and deutectomy on plasma free fatty acids (FFA) were investigated in 210 sexed Shaver Starcross cockerels in the first week after hatching.

At the end of hatching the FFA concentration in plasma of chickens was $1.0 \pm 0.2 \mathrm{mmol} .1^{-1}$. During the 2-hour long transport it increased.

On the other hand, upon 1-hour long exposure to $18^{\circ} \mathrm{C}$ a decrease was noted in plasma FFA concentration in chicks exposed to cold both before and after transport as against the values found at $35^{\circ} \mathrm{C}$. The intact fed birds aged 2,3 and 4 days showed no changes, whereas a substantial increase in plasma FFA to values exceeding those of the first day were found in birds aged 5 days.

Chickens deprived of food and held at $35^{\circ} \mathrm{C}$ and those exposed to $18{ }^{\circ} \mathrm{C}$ showed higher plasma FFA concentrations than fed birds. It is suggested that fasting results in mobilization of lipid stores shortly after hatching whereas upon exposure to cold thermoregulation mechanisms operative in adults seem not to operate till the end of the first week after hatching.

There were no substantial differences in plasma FFA concentration between the intact and deutectomized birds. The results show that deutectomy has no major effect on plasma FFA concentration as compared to intact birds, i.e. that the substrates of lipid metabolism after completed hatching do not originate in the yolk sac itself.
\end{abstract}

Age changes, food deprivation, yolk sac, transport.

In an earlier study carbohydrate content of the body fluid compartments and livers of newly hatched chickens was found to be dependent upon the onset of food intake after hatching $(\mathrm{Ba}$ ranyiová 1972), with the yolk sac providing no substrate to sustain plasma glucose levels in fasting birds. However, the main components of the yolk sac are lipids. We therefore decided to investigate the levels of their transport form - free fatty acids (FFA) - in blood plasma of chickens in the first week after hatching under standard nutritional and temperature conditions as against fasting, exposure to decreased ambient temperature and deutectomy.

\section{Materials and Methods}

In the experiment, 210 newly hatched, sexed Shaver Starcross cockerels were employed. At th: end of hatching (with down feathers still wet) 5 birds were blood-sampled and 5 were exposed to $18{ }^{\circ} \mathrm{C}$ for one hour before blood sampling. Immediately after a 2-hour long transport to laboratory 5 blood samples were taken and another group of 5 cockerels was exposed to $18{ }^{\circ} \mathrm{C}$ for one 
hour before blood sampling. Half of the remaining birds were deutectomized and half were left untreated to serve as intact controls. Half of the birds in each of these groups were deprived of food, but had access to drinking water. The other half of birds in each group were fed ad lib. a commercial diet. The birds were kept in batteries at $35^{\circ} \mathrm{C}$. The effect of low ambient temperature
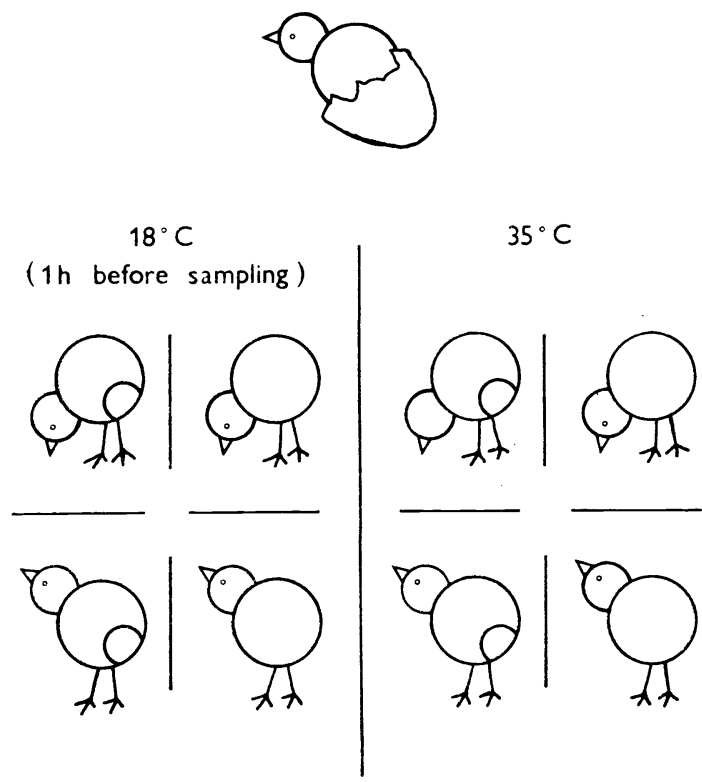

Fig. 1.

Design of the experimental groups of chickens. was studied in chickens exposed to $18^{\circ} \mathrm{C}$ for one hour.

Five birds each of all above mentioned groups were blood-sampled invariably at the same time of the day after minimum handling. Two plasma samples $(50 \mu \mathrm{l})$ from each bird were analyzed.

Total plasma FFA concentration was determined by the spectrophotometric ultramicromethod (Novák 1965) as modified by Votruba et al. (1974). The classical titration method (Trou t et al. 1960) was used as a check on the accuracy of the aforementioned method in a preliminary study.

The results were evaluated statistically by the Student's t-test.

\section{Results}

The concentration of FFA in the blood plasma of chickens at the end of hatching was $1.0 \pm$ $\pm 0.1 \mathrm{mmol} \mathrm{.1} \mathbf{m}^{-1}$ (Tab. 1). After the transport from the hatchery a remarkably increased $(\mathbf{P}<$ $<0.001)$ plasma FFA concentration up to $3.2 \pm 0.2 \mathrm{mmol} .1^{-1}$ was observed. Within 24 hours it was lower $(P<0.001)$ in all 4 groups (i.e. intact fed, deutectomized fed, intact fasted and deutectomized fasted) of chicks held at $35^{\circ} \mathrm{C}$, and it decreased significantly only in deutectomized fed $(P<0.02)$ and deutectomized fasted $(P<0.05)$ birds as against the values found at the end of hatching. The fasted intact birds had higher FFA concentration than the fed

Table 1

Concentration of free fatty acids in the blood plasma of chickens in $\mathrm{mmol}^{-\mathrm{1}^{-1}}$

\begin{tabular}{|c|c|c|c|c|c|}
\hline \multirow{2}{*}{$\begin{array}{l}\text { Day after } \\
\text { hatching }\end{array}$} & \multirow{2}{*}{ Experimental group } & \multicolumn{2}{|c|}{$35^{\circ} \mathrm{C}$} & \multicolumn{2}{|c|}{$18^{\circ} \mathrm{C}$} \\
\hline & & Fed & Fasted & Fed & Fasted \\
\hline 1 & $\begin{array}{l}\text { Prior to transport } \\
\text { After } 2 \mathrm{~h} \text { transport }\end{array}$ & & $\begin{array}{l}1.0 \pm 0.2 \\
3.2 \pm 0.2\end{array}$ & & $\begin{array}{l}0.8 \pm 0.1 \\
1.8 \pm 0.1\end{array}$ \\
\hline 2 & $\begin{array}{l}\text { Intact } \\
\text { Deutectomized }\end{array}$ & $\begin{array}{l}0.6 \pm 0.2 \\
0.4 \pm 0.1\end{array}$ & $\begin{array}{l}1.1 \pm 0.2 \\
0.3 \pm 0.1\end{array}$ & $\begin{array}{l}0.7 \pm 0.0 \\
0.6 \pm 0.1\end{array}$ & $\begin{array}{l}1.1 \pm 0.1 \\
0.8 \pm 0.1\end{array}$ \\
\hline 3 & $\begin{array}{l}\text { Intact } \\
\text { Deutectomized }\end{array}$ & $\begin{array}{l}0.5+0.1 \\
0.8 \pm 0.1\end{array}$ & $\begin{array}{l}1.2 \pm 0.1 \\
0.9 \pm 0.1\end{array}$ & $\begin{array}{l}0.5 \pm 0.1 \\
0.5 \pm 0.1\end{array}$ & $\begin{array}{l}1.5 \pm 0.2 \\
1.2 \pm 0.2\end{array}$ \\
\hline 4 & $\begin{array}{l}\text { Intact } \\
\text { Deutectomized }\end{array}$ & $\begin{array}{l}0.8 \pm 0.1 \\
1.1 \pm 0.2\end{array}$ & $\begin{array}{l}1.2 \pm 0.2 \\
1.1 \pm 0.3\end{array}$ & $\begin{array}{l}0.7 \pm 0.1 \\
0.8 \pm 0.1\end{array}$ & $\begin{array}{l}1.6 \pm 0.2 \\
0.8 \pm 0.2\end{array}$ \\
\hline 5 & $\begin{array}{l}\text { Intact } \\
\text { Deutectomized }\end{array}$ & $\begin{array}{l}0.9 \pm 0.1 \\
2.1 \pm 0.4\end{array}$ & $\begin{array}{l}0.6 \pm 0.2 \\
0.5 \pm 0.3\end{array}$ & $\begin{array}{l}2.0 \pm 0.2 \\
2.6 \pm 0.2\end{array}$ & $\begin{array}{l}0.9 \pm 0.2 \\
0.3 \pm 0.0\end{array}$ \\
\hline
\end{tabular}


ones on day 2 and $3(P<0.01)$, the deutectomized fasted birds had lower plasma FFA concentrations than the intact ones on day $2(P<0.01)$. Up to day 5 , the plasma FFA increased moderately in both groups of fed chickens, with values somewhat higher in deutectomized birds. In chickens of both fasted groups the plasma FFA concentration decreased between days 4 and 5 .

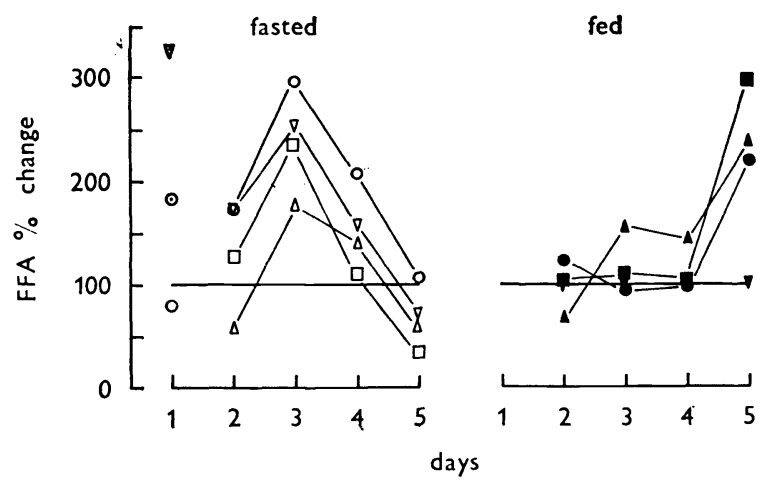

Fig. 2.

Percentage change in plasma FFA: the values found in intact fed birds held at $35^{\circ} \mathrm{C}$ served as reference value $(100 \%)$ each day.

Open symbols - fasted birds, closed symbols - fed birds.

$\nabla$ intact birds at $35^{\circ} \mathrm{C}$

$\triangle$ deutectomized birds at $35^{\circ} \mathrm{C}$

$\mathrm{O}$ intact birds at $18^{\circ} \mathrm{C}$

deutectomized birds at $18^{\circ} \mathrm{C}$

birds blood-sampled after the transport

$\odot$ birds blood-sampled after the transport and $1 \mathrm{~h}$ exposure to $18^{\circ} \mathrm{C}$ thereafter

In hatched chickens exposed to $18^{\circ} \mathrm{C}$ no changes in plasma FFA concentration were noted. On the other hand, after the transport followed by an exposure to $18^{\circ} \mathrm{C} 1.8 \pm 0.1 \mathrm{mmol} .1^{-1} \mathrm{FFA}$ was found, i.e. value significantly $(\mathrm{P}<0.001)$ higher than that prior to but lower $(\mathrm{P}<0.001)$ than after transport at $35^{\circ} \mathrm{C}$. In 2-, 3- and 4-day old intact fed chickens no such changes were observed upon exposure to $18{ }^{\circ} \mathrm{C}$. On the other hand, in intact fasted birds aged 2, 3 and 4 days, the plasma FFA concentration rose significantly $(\mathrm{P}<0.01, \mathrm{P}<0.001, \mathrm{P}<0.05)$ in response to exposure to cold. On day 5 the plasma FFA of both intact and deutectomized fasted chickens fell considerably upon exposure to $18{ }^{\circ} \mathrm{C}$, whereas both fed groups showed a significant increase in plasma FFA from $0.8 \pm 0.1 \mathrm{mmol} .1^{-1}$ on day 4 to $2.6 \pm 0.2 \mathrm{mmol} .1^{-1}$ on day $5(\mathrm{P}<0.001)$ in deutectomized birds and from $0.7 \pm 0.1 \mathrm{mmol} .1^{-1}$ to $2.0 \pm 0.2 \mathrm{mmol}^{-1}$ on day $5(\mathrm{P}<0.05)$ in intact birds. In fasted chickens exposed to $18^{\circ} \mathrm{C}$ had the deutectomized birds lower FFA concentration on days $2(P<0.05)$ and $5(P<0.05)$ than the intact birds.

\section{Discussion}

The plasma FFA concentration decreased in chickens exposed to $18{ }^{\circ} \mathrm{C}$ for one hour both at the end of hatching and after the transport. This finding is at variance with the data of Freeman (1967). On the other hand, the transport itself led to almost 3.5 times higher FFA concentration in chicks at $35^{\circ} \mathrm{C}$. Obviously, the 
stress of manipulation and transport caused this increase. Similar findings in older birds were reported by others (Freeman and Manning 1976; Freeman 1976a).

By 24 hours after hatching the plasma FFA concentration had decreased significantly reaching values reported for older birds (Langslow and Freeman 1973; Freeman 1976b) held at optimum temperature and fed ad lib.

On days 2,3 and 4 we found no increase in plasma FFA of fed chickens exposed to $18{ }^{\circ} \mathrm{C}$ for 1 hour. Such response was only detected in the chicks deprived of food at the same age and it was even more pronounced in these (i.e. fasted) birds exposed to $18{ }^{\circ} \mathrm{C}$ at the age of 2,3 and 4 days $(\mathrm{P}<0.01 ; \mathrm{P}<0.001 ; \mathrm{P}<0.05)$.

These findings suggest that fasting can mobilize body fat reserves, manifested by elevated FFA levels, as soon as the 2nd day after hatching; at this age fasting was also shown to increase plasma corticosterone levels (Constantin et al. 1977).

On the other hand, in fed chickens plasma FFA concentration in response to cold increased only at 5 days of age when it rose 2.9 times in the intact and 3.3 times in the deutectomized birds as against the values of the 4th day.

This finding shows that chickens mobilize their lipid reserves in response to cold accompanied by increased FFA concentration only at the end of the first posthatching week and supports the conclusions of Wekstein and Zolman $(1967,1969,1970)$ that the homeothermic development of chickens is correlated to age rather than to body mass increase or feather insulation. Upon 2-hour exposure to $10^{\circ} \mathrm{C}$ a fivefold increase in plasma FFA levels of chickens was reported by Freeman (1976b).

In the light of observations on the lipid occurrence (Bar anyio vá and Holman 1972) and metabolism in chickens during and shortly after hatching (Langslow and Lewis 1972) and present data the possibility should be considered that to these characteristics also the minimum intestinal absorption of dietary animal fat in the youngest birds may be related. Substantial changes in dietary lipid absorption were noted only in chickens 10-13 days old (Carew et al. 1972).

The high concentration of plasma FFA during the first posthatching week in our deutectomized chickens can be taken as evidence of their origin from lipid depots accumulated before hatching.

The present results indicate that in chickens the mechanisms underlying the response to fasting by FFA mobilization operate as soon as the second day after hatching whereas those responsible for FFA mobilization upon exposure to cold apparently do not start to operate till the end of the first week after hatching.

\section{Vplyv deutektómie, hladovania a teploty prostredia na obsah volných mastných kyselín v krvnej plazme kurčiat v prvom týždni po vyliahnutí}

$\mathrm{V}$ pokuse na 210 kohútikoch Shaver Starcross sme sledovali vplyv prijmu potravy, hladovania, teploty prostredia a deutektómie na obsah VMK $\mathrm{v}$ plazme v prvom týždni po vyliahnutí.

Na konci liahnutia bola plazmatická koncentrácia VMK v plazme kurčiat $1,0 \pm 0,2 \mathrm{mmol} .1^{-1}$. Po 2-hodinovom transporte sa podstatne zvýšila, a to zvlášt' pri teplote $35^{\circ} \mathrm{C}$.

Koncentrácia VMK v plazme kurčiat krmených intaktných sa po 1-hodinovom pobyte $\mathrm{v}$ teplote $18^{\circ} \mathrm{C}$ na 2 ., 3. a 4 . deň oproti kontrolám pri $35^{\circ} \mathrm{C}$ nemenila, 
ale na 5 . deň pri vystavení chladu vzrástla výrazne na hodnoty prevyšujúce nálezy prvého dňa.

Na kurčatách hladujúcich pri $35^{\circ} \mathrm{C}$ a pri $18{ }^{\circ} \mathrm{C}$ sme v porovnaní s krmenými vtákmi našli vyššie hladiny plazmatických VMK. Zdá sa teda, že hladovanie vedie $\mathbf{k}$ mobilizácii lipidových rezerv už od počiatku postinkubačného života, zatialčo pri vystavení chladu sa komponenty chemickej termoregulácie, známe u dospelých jedincov, začínajú objavovat až koncom prvého týždňa života kurčiat.

Medzi kurčatami intaktnými a deutektomovanými sme podstatné rozdiely v obsahu plazmatických VMK nenašli.

$Z$ výsledkov pokusu je zrejmé, že deutektómia plazmatickú hladinu VMK kurčiat $\mathrm{v}$ porovnaní $\mathrm{s}$ intaktnými vtákmi neovplyvnila, tj. že substráty lipidového metabolizmu po ukončenom liahnutí nepochádzajú zo žltkového vaku.

\section{Влияние дейтектомии, голодовки и температуры окружающей среды на содержание свободных жирных кислот в кровяной плазме цыплят на первой неделе после вылупления}

В ходе опыта с 210 петушками Shaver Starcoss проводились наблюдения за влиянием приема пищи, голодовки, температуры окружающей среды и дейтектомии на содержание свободных жирных кислот в плазме на первой неделе их жизни.

Самое большое содержание плазматических свободных жирных кислот было установлено после вылупления цыплят. Количество свободных жирных кислот до второго дня понизилось в общем у всех подопытных групп на одну треть.

Интактные и кормленные цыплята, перед и после транспорта, находящиеся p течение часа в холоде $\left(18{ }^{\circ} \mathrm{C}\right)$, отвечали первый день понижением уровня жирных свободных кислот в плазме, на второй, третий и четвертый дни и уровень по сравнению с контролными группами при $35{ }^{\circ} \mathrm{C}$, стал неизменным, однако, на пятый день при содержании в холоде наблюдалось выразительное увеличение свободных жирных кислот до величины, превосходящей установленную величину первого дня.

У голодающих при $35{ }^{\circ} \mathrm{C}$ и при $18{ }^{\circ} \mathrm{C}$ цыплят, по сравнению с кормленной птицей, нами были выявлены более высокие уровни плазматических свободных жирных кислот. Выходит, следовательно, что голодовка приводит к мобилизаџии липидных резервов уже в начале жизни после вылупления, между тем как при нахождении в холоде компоненты химической терморегулировки, известные у взрослых куриц, начинают проявляться лишь в конце первой недели жизни цыплят.

Между незатронутыми и подвергшимися дейтектомии цыплятами не была выявлена существенная разница в содержании плазматических свободных жирных кислот.

Исходя из опыта, следует сделать вывод, что дейтектомия, по сравнению с незатронутыми цыплятами, не оказала влияния на уровень плазматических свободных жирных кислот, следовательно, что субстраты липидного метаболизма после завершенного вылупления не связаны с желточным мешком. 


\section{References}

BARANYIOVÁ, E.: Vplyv prijmu potravy a hladovania na rozmery tráviaceho traktu a na obsah glycidov v tele deutektomovaných a intaktných kurčiat. PhD. Thesis, Brno, 1972, 198 pp.

BARANYIOVÁ, E. - HOLMAN, J.: Lipid droplets in hepatocytes of chicken embryos and chickens after hatching. Acta vet. Brno, 41, 1972: 367-372.

CAREW, L. B. J. - MACHEMER, R. H. Jr. - SHARP, R. W. - FOSS, D. C.: Fat absorption by the very young chick. Poultry Sci., 51, 1972: 738-742.

CONSTANTIN, N. - RASZYK, J. - HOLUB, A. - KOTRBÁČEK, V.: Effect of adrenocorticotrophic hormone and starvation on adrenocortical function in chickens during the early posthatching period. Acta vet. Brno, 46, 1977: 87-93.

FREEMAN, B. M.: Some effects of cold on the metabolism of the fowl during the perinatal period. Comp. Biochem. Physiol., 20, 1967: 179-193.

FREEMAN, B. M.: Effect of noradrenaline on the plasma free fatty acids and glucose levels in Gallus domesticus. Comp. Biochem. Physiol., 30, 1969: 993-996.

FREEMAN, B. M. - MANNING, A. C. C.: Mediation of glucagon in the response of the domestic fowl to stress. Comp. Biochem. Physiol. 53 A, 1976: 169-171.

FREEMAN, B. M.: Thermoregulation in the young fowl (Gallus domesticus). Comp. Biochem. Physiol., 54 A, 1976a: $141-144$.

FREEMAN, B. M.: Physiological responses to stress with reference to the domestic fowl. Laboratory Animals, 10, 1976b: $385-388$.

LANGSLOW, D. R. - LEWIS, R. J.: The compositional development of adipose tissue in Gallus domesticus. Comp. Biochem. Physiol, 43 B, 1972: 681-688.

LANGSLOW, D. R. - FREEMAN, B. M.: Investigations in to the mode of action of synthalin A in Gallus domesticus. Comp. Biochem. Physiol., 46 A, 1973: 447-462.

NOVÁK, M.: Colorimetric ultramicromethod for the determination of free fatty acids. J. Lipid Res., 6, 1965: 430-433.

TROUT, D. L. - ESTES, E. H. - FRIEDBERG, S. J.: Titration of free fatty acids of plasma: a study of current methods and a new modification. J. Lipid Res., 1, 1960: 199-200.

VOTRUBA, M. - SAKAR̆OVÁ, V. - ROUCHAL, J.: Metodiky pro stanovení frakcí lipidů. Sborník OKB FN KÚNZ Hradec Králové, 1974.

WEKSTEIN, D. R. - ZOLMAN, J. F.: Homeothermic development of the young chick. Proc. Soc. exp. Biol. Med., 125, 1967: 294-297.

WEKSTEIN, D. R. - ZOLMAN, J. F.: Ontogeny of heat production in chicks. Fedn Proc. Fedn Am. Soc. exp. Biol., 28, 1969: 1023-1028.

WEKSTEIN, D. R. - ZOLMAN, J. F.: Homeothermic development of young scaleless chicks. Br. Poult. Sci., 11, 1970: 399-402. 